\title{
Examination of strains belonging to enteropathogenic Escherichia coli serogroups for genes encoding EPEC adherence factor and Vero cytotoxins
}

\author{
H. R. SMITH, S. M. SCOTLAND, N. STOKES and B. ROWE
}

Division of Enteric Pathogens, Central Public Health Laboratory, 61 Colindale Avenue, London NW9 5HT

\begin{abstract}
Summary. Four hundred and forty-nine strains isolated from patients with diarrhoea and belonging to 13 enteropathogenic Escherichia coli (EPEC) $\mathrm{O}$ serogroups were tested with a DNA probe for the EPEC adherence factor (EAF). Positive results were obtained with only 36 strains; they belonged to $10 \mathrm{O}$ serogroups and flagellar typing showed they were usually of the "classical" EPEC serotypes. Thirty-four of the 36 EAF-positive strains showed localised adhesion to HEp-2 cells. The two remaining strains, of serotypes $0114: \mathrm{H} 2$ and $0127: \mathrm{H} 4$, showed low level or no adhesion to HEp-2 cells. No colonies hybridising with the EAF probe were identified in cultures from 115 faecal specimens from healthy children. Sixteen of the 449 strains hybridised with one or both probes for the Vero cytotoxin genes VT1 and VT2; 15 of the 16 strains belonged to serogroups O26 and O128. None of the strains hybridised with both the EAF and VT gene probes. These studies show that the great majority of strains belonging to EPEC O serogroups do not possess the EPEC adherence factor or carry VT genes.
\end{abstract}

\section{Introduction}

Strains of Escherichia coli associated with diarrhoeal disease have been divided into four main groups: enterotoxigenic E.coli (ETEC), enteropathogenic E. coli (EPEC), enteroinvasive E.coli(EIEC) and Vero cytotoxin-producing $E$. coli (VTEC). EPEC are strains belonging to particular serotypes that have been associated epidemiologically with outbreaks of infantile enteritis. ${ }^{1}$ A number of EPEC strains from outbreaks have been examined for virulence properties but they did not produce heat-stable or heat-labile enterotoxins or Vero cytotoxins. ${ }^{2,3}$ Because EPEC have the ability to colonise the small intestine the adhesive properties of these organisms have been examined in vitro. A study of the adherence of EPEC strains to HEp-2 cells grown in tissue culture showed that $80 \%$ of strains isolated from outbreaks of diarrhoea were adhesive. ${ }^{4}$ Three patterns of adhesion of diarrhoeagenic $E$. coli strains to HEp-2 or HeLa cells have been reported; these have been termed localised adherence, diffuse adherence and aggregative. ${ }^{5-7}$

In strain E2348/69, of serotype O127:H6, the presence of a plasmid designated pMAR2 was required for full expression of localised HEp-2 adhesion and this plasmid has been termed the

Received 7 Aug. 1989 ; accepted 6 Oct. 1989.
EPEC adherence factor (EAF) plasmid. ${ }^{8,9}$ The importance of pMAR2 in the virulence of E2348/ 69 was clearly shown in volunteer studies in which nine of 10 healthy adults suffered diarrhoea after challenge with E2348/69 but only two of nine subjects had diarrhoea after receiving the derivative strain lacking pMAR2. ${ }^{10}$ Cloning and mapping of plasmid pMAR2 led to the development of a DNA probe comprising a 1-kb Sall-BamHI fragment. ${ }^{11,12}$ This probe, designated the EAF probe, has been used in several studies in different parts of the world and the results have been correlated with HEp-2 adhesion assays. ${ }^{9,12-16}$ In most studies there was a $100 \%$ correlation between hybridisation with the EAF probe and localised adherence to HEp-2 cells and all these strains belonged to the most common EPEC O serogroups. However, in a recent paper, Levine et al. ${ }^{16}$ reported that only 77 of 85 EAF-positive strains showed localised adherence but the properties of the remaining eight strains were not described.

The production of Vero cytotoxin (VT) by some strains belonging to EPEC serogroups has been reported. ${ }^{3,17,18}$ Two types of VT, designated VT1 and VT2, have been identified by toxin neutralisation experiments ${ }^{19}$ and DNA probes for the phage genes encoding VT1 and VT2 have been developed. $^{20}$ EPEC strains from outbreaks did not 
produce VT but some strains of serogroups $\mathrm{O} 26$ and $\mathrm{O} 128$ from sporadic cases of diarrhoea gave positive results in Vero-cell assays and hybridised with the VT probes. ${ }^{3,18}$

Previous studies showed that within the EPEC O serogroups only strains with certain flagellar $(\mathrm{H})$ antigens were isolated commonly from infants with diarrhoea. ${ }^{21}$ The adhesive properties of strains isolated in the United Kingdom that belonged to serotypes associated with outbreaks of infantile enteritis have been described. ${ }^{22}$ It was concluded that strains from sporadic cases of diarrhoea, belonging to the same serotypes as the outbreak strains, often showed localised adherence and hybridisation with the EAF probe.

In this study we have examined $E$. coli strains belonging to any $\mathrm{H}$ type of 13 EPEC $\mathrm{O}$ serogroups. Colony hybridisation was used to test the strains with DNA probes for EAF, VT1 and VT2. The positive results with the EAF probe were correlated with the ability to adhere to HEp-2 cells. Additionally, faecal samples from healthy infants were examined to show whether strains hybridising with the EAF probe were present.

\section{Materials and methods}

\section{Bacterial strains and faecal specimens}

The strains had been sent to the Division of Enteric Pathogens (DEP) between Jan. 1985 and Dec. 1987. They were isolated from cases of diarrhoea; 353 were from the UK and 96 were isolated abroad or on return to the UK after foreign travel. The strains were identified biochemically ${ }^{23}$ and serotyped. ${ }^{24}$

Faecal specimens from 115 healthy children were examined for the presence of strains hybridising with the EAF probe. The specimens had been submitted to the DEP for separate studies investigating the role of VTEC.

\section{Tissue culture adhesion and actin accumulation tests}

Tests for adhesion to HEp-2 cells and Intestine 407 cells were performed as described by Scotland et al. ${ }^{22,25}$ Cells were examined for attached bacteria after fixing with methanol and staining with Giemsa stain. The fluorescence actin staining test (FAS test) was done as described by Knutton et al. ${ }^{26}$ Briefly HEp-2 cells were fixed with formaldehyde $3 \% \mathrm{w} / \mathrm{v}$ at the end of an adhesion test. Cells were rendered permeable with Triton X-100 $0.1 \% \mathrm{v} / \mathrm{v}$ in phosphate-buffered saline (PBS), treated with fluorescein isothiocyanate-phalloidin (Sigma) $5 \mu \mathrm{g} / \mathrm{ml}$ in PBS and examined for the presence of fluorescing accumulations of filamentous actin beneath attached bacteria by consecutive incident light fluorescence and phase-contrast microscopy on the same specimen.

\section{DNA hybridisation tests}

Broth cultures of the strains were spotted on Hybond$\mathrm{N}$ nylon membranes placed on MacConkey agar plates; controls of known probe-positive and -negative strains were included on each membrane. Faecal specimens were suspended in an equal volume of PBS and $0 \cdot 1-\mathrm{ml}$ samples of 10-fold dilutions were spread on MacConkey agar plates. Plates with several hundred colonies were replicated on to nylon membranes placed on MacConkey agar. For both types of sample the plates were incubated at $37^{\circ} \mathrm{C}$ for $6 \mathrm{~h}$ and prepared for colony hybridisation. ${ }^{27}$

The EAF probe was a 1-kb SalI-BamHI fragment isolated from a derivative of plasmid pMAR2. ${ }^{11}$ The VT1 probe was a $0 \cdot 75-\mathrm{kb}$ HincII fragment derived from the VTl-encoding phage isolated from $E$. coli strain H19. ${ }^{28}$ The VT2 probe was a $0 \cdot 85-\mathrm{kb}$ Aval-Pst I fragment present in VT2 sequences cloned from a VT2-encoding phage in E. coli strain, E32511. ${ }^{20}$ The probe fragments were separated by electrophoresis in low temperature gelling agarose $1 \% \mathrm{w} / \mathrm{v}$. The bands were cut from the gel and labelled with deoxyadenosine $5^{\prime}-\alpha-\left({ }^{35} S\right)$ thiotriphosphate by the random primer method. ${ }^{29}$

DNA hybridisation was at $42^{\circ} \mathrm{C}$ in a mixture containing: formamide $50 \%, 5 \times \operatorname{SSPE}(1 \times \mathrm{SSPE}, \mathrm{pH} 7.4$, is $0.18 \mathrm{M} \mathrm{NaCl}, 10 \mathrm{~mm} \mathrm{NaH}{ }_{2} \mathrm{PO}_{4}$ and $1 \mathrm{~mm}$ EDTA); Ficoll (mol. wt 400000 ), polyvinylpyrrolidone, bovine serum albumin and sodium dodecyl sulphate (SDS) $0.1 \%$ each; $0.01 \mathrm{M}$ dithiothreitol and denatured salmon sperm DNA $100 \mu \mathrm{g} / \mathrm{ml}$. Washing under high stringency conditions and autoradiography were done as described by Willshaw et al. ${ }^{28}$

\section{Results}

Testing of strains and faecal specimens with the EAF probe

Three hundred and fifty-three $E$. coli strains, isolated in the UK and belonging to $13 \mathrm{O}$ serogroups, were tested for hybridisation with the EAF probe (table I).

Twenty-three strains $(6.5 \%)$ gave positive results; they belonged to eight of the $13 \mathrm{O}$ serogroups. In most cases the EAF-positive strains were of particular $\mathrm{O}: \mathrm{H}$ combinations, including some nonmotile strains, that have been associated with outbreaks of infantile enteritis. ${ }^{4,22}$ However, two strains of serotypes O125ac:H22 and O142:H34 belonged to types that have not been described as EAF-positive in previous studies. Strains of serogroups $\mathrm{O} 18, \mathrm{O} 26$ and $\mathrm{O} 128$ comprised 116 of the 353 strains but none showed hybridisation with the EAF probe. The EAF probe-negative strains belonged to a wide range of different $\mathrm{H}$ types although, within certain serogroups, the majority of strains were of one H-type. Examples, shown in 
Table I. Examination of $E$. coli belonging to enteropathogenic $\mathrm{O}$ serogroups isolated in the UK from sporadic cases of diarrhoea (1985-1987)

\begin{tabular}{|c|c|c|c|c|}
\hline O serogroup & $\begin{array}{c}\text { Number } \\
\text { tested }\end{array}$ & $\begin{array}{l}\text { Number positive } \\
\text { with the EPEC ad- } \\
\text { herence factor probe }\end{array}$ & $\begin{array}{c}\text { H type of } \\
\text { probe-positive } \\
\text { strains } \\
\text { (number of strains) }\end{array}$ & $\begin{array}{l}\mathrm{H} \text { type of probe-negative strains } \\
\text { (number of strains) }\end{array}$ \\
\hline 18 & 41 & 0 & .. & $1(1), 5(5), 7(20), 25(1), 28(1), 56(1), \mathrm{H}-(12)$ \\
\hline $26^{*}$ & 30 & 0 & .. & $2(1), 11(10), 21(1), 26(1), 32(1), \mathrm{H}-(16)$ \\
\hline 44 & 16 & 0 & & $15(1), 18(14), \mathrm{H}-(1)$ \\
\hline 55 & 38 & 1 & $\mathrm{H}-$ & $\begin{array}{l}1(1), 7(16), 9(2), 10(1), 14(1), 27(2), 31(1), 34(5), 35(1), \\
36(1), \mathrm{H} \text { rough(1), H-(5) }\end{array}$ \\
\hline 86 & 13 & 0 & . & $\begin{array}{l}2(1), 4(1), 8(3), 10(1), 18(1), 27(1), 30(1), 43(1), 51(1), \\
H-(2)\end{array}$ \\
\hline $111 \mathrm{ab}$ & 35 & 4 & $\mathrm{H}-(4)$ & $\begin{array}{l}4(1), 12(2), 16(1), 21(11), 25(10), 29(1), 43(1), H \\
\text { rough(1), H-(3) }\end{array}$ \\
\hline $111 \mathrm{ac}$ & 2 & 0 & & $4(1), \mathrm{H}-(1)$ \\
\hline 114 & 11 & 3 & 2(3) & $4(1), 5(1), 9(2), 25(2), 49(1), \mathrm{H}-(1)$ \\
\hline 119 & 9 & 3 & $6(2), H-(1)$ & 2(4), 4(1), H-(1) \\
\hline $125 \mathrm{ab}$ & 6 & 0 & & $6(4), 19(1), \mathrm{H}-(1)$ \\
\hline $125 \mathrm{ac}$ & 30 & 3 & $22(1), \mathrm{H}-(2)$ & $6(14), 9(1), 11(1), 19(1), 21(1), 30(5), 43(1), \mathrm{H}-(3)$ \\
\hline 126 & 34 & 1 & $\mathrm{H}-$ & $\begin{array}{l}5(1), 6(4), 9(1), 11(1), 12(1), 15(1), 20(1), 21(1), 26(1), \\
27(20), 45(1)\end{array}$ \\
\hline 127 & 28 & 5 & $4(1), 6(3), H-(1)$ & $4(2), 7(1), 11(1), 21(1), 27(1), 28(1), 40(6), 45(5), \mathrm{H}-(5)$ \\
\hline $128 \dagger$ & 45 & 0 & & $\begin{array}{l}1(1), 2(16), 8(6), 9(1), 11(1), 12(3), 21(1), 25(1), 28(1), \\
30(1), 35(5), 47(1), 49(1), H-(6)\end{array}$ \\
\hline 142 & 15 & 3 & $6(2), 34(1)$ & $1(1), 6(2), 11(1), 34(4), 36(2), 38(1), \mathrm{H}$ rough $(1)$ \\
\hline Total & 353 & 23 & & \\
\hline
\end{tabular}

*Nine strains of serogroup $\mathrm{O} 26$ hybridised with the VTI probe; eight strains were $\mathrm{O} 26: \mathrm{H} 11$ and one was $\mathrm{O} 26: \mathrm{H}-$.

†Three strains of serogroup O128 hybridised with the VT1 and VT2 probes; two strains were O128ab:H2 and one was O128ab:H - .

table I, are strains of O18: $\mathrm{H} 7, \mathrm{O} 26: \mathrm{H} 11, \mathrm{O} 44: \mathrm{H} 18$, $\mathrm{O} 55: \mathrm{H} 7, \mathrm{O} 125 \mathrm{ac}: \mathrm{H} 6, \mathrm{O} 126: \mathrm{H} 27$ and O128:H2. The EAF probe-negative strains were also examined for $\mathrm{O}: \mathrm{H}$ combinations that have been reported as EAF-positive in previous studies, particularly those associated with outbreaks of enteritis. Strains that fell into this class belonged to serotypes O127:H4 (two strains), O128:H2 (16 strains) and O142: H6 (two strains) (table I).

Ninety-six strains isolated from persons infected abroad were also examined; the strains belonged to $12 \mathrm{O}$ serogroups as this series contained no strains of serogroup O26. Thirteen strains $(14 \%)$ gave positive hybridisation results with the EAF probe (table II). All these EAF-positive strains belonged to serotypes that have been reported as EAFpositive in other studies. In the present study, EAFpositive strains of serotypes $\mathrm{O} 55: \mathrm{H} 6, \mathrm{O} 86: \mathrm{H}-$, $\mathrm{O} 11 \mathrm{lab}: \mathrm{H} 2$ and $\mathrm{O} 128: \mathrm{H} 2$ were detected in persons infected abroad but not in the strains isolated in the UK (table I).

One hundred and fifteen faecal specimens from healthy children were tested as described in the Methods. No colonies hybridising with the EAF probe were identified.

\section{Adhesion tests}

The 36 EAF-positive strains were examined for adhesion to HEp-2 cells in a 6-h test. Thirty-four of the strains showed localised adhesion to at least $30 \%$ and usually more than $70 \%$ of HEp- 2 cells but there was little or no adhesion with the remaining two strains. These two strains, designated E29452 and E36594, belonged to serotypes O127:H4 and $\mathrm{O} 114: \mathrm{H} 2$ respectively and both were isolated in the UK. Single colonies of the two strains were then tested. Two EAF-positive colonies of E29452 (O127:H4) showed no adhesion to HEp-2 or Intestine 407 cells. Five EAF-positive colonies of E36594 (O114:H2) adhered to $12 \%$ or less of HEp2 or Intestine 407 cells. Attachment was of the typical localised pattern and was associated with the formation of actin fluorescence.

\section{Testing of strains with probes for VT1 and VT2}

Since production of Vero cytotoxin has been reported for some strains belonging to EPEC $\mathrm{O}$ serogroups, the 449 strains were tested for hybridisation with DNA probes for VT1 and VT2. Sixteen strains gave positive results with VT1 or VT2 or 
Table II. Examination of $E$. coli belonging to enteropathogenic $O$ serogroups isolated from cases of diarrhoea abroad or on return to the UK after foreign travel (1985-1987)

\begin{tabular}{lcccc}
\hline O serogroup & $\begin{array}{c}\text { Number } \\
\text { tested }\end{array}$ & $\begin{array}{c}\text { Number positive with } \\
\text { the EPEC adherence } \\
\text { factor probe }\end{array}$ & $\begin{array}{c}\text { H type of probe-positive } \\
\text { strains } \\
\text { (number of strains) }\end{array}$ & \multicolumn{1}{c}{$\begin{array}{c}\text { H type of } \\
\text { probe-negative } \\
\text { strains } \\
\text { (number of strains) }\end{array}$} \\
\hline 18 & 5 & 0 & $\ldots$ & $1(1), 3(1), 53(1), \mathrm{H}-(2)$ \\
44 & 4 & 0 & $\ldots$ & $1(1), 18(1), 24(1), 34(1)$ \\
55 & 8 & 3 & $6(3)$ & $19(1), 27(1), \mathrm{H}-(3)$ \\
86 & 7 & 1 & $\mathrm{H}-$ & $2(1), 10(1), 18(3), 27(1)$ \\
$111 \mathrm{ab}$ & 6 & 2 & $2(2)$ & $1(1), 2(1), 21(1), \mathrm{H}-(1)$ \\
$111 \mathrm{ac} *$ & 2 & 0 & $\ldots$ & $8(1), \mathrm{H}-(1)$ \\
114 & 6 & 0 & $6(4)$ & $49(1), \mathrm{H}$ rough(1), H-(4) \\
119 & 4 & 4 & $\mathrm{H}-$ & $4(1), 21(2), \ldots$ \\
$125 \mathrm{ac}$ & 4 & 1 & $\mathrm{H}-$ & $2(1), 6(2), 12(9), 29(1), 30(3), \mathrm{H}-(1)$ \\
126 & 18 & 1 & $\ldots$ & $4(2), 12(1), 29(1), 40(2), 54(1)$ \\
127 & 7 & 0 & 2 & $1(1), 2(2), 4(1), 8(2), 10(1), 12(8), 30(2), 31(1)$, \\
$128 \dagger$ & 24 & 1 & $\ldots$ & $34(1), 35(1), 36(1), 47(1), \mathrm{H}$ rough $(1)$ \\
142 & 1 & 0 & & $7(1)$ \\
Total & 96 & 13 & & \\
\hline
\end{tabular}

*One strain of serotype 0111 ac: $\mathrm{H} 8$ hybridised with the VT1 probe.

†Three strains of serogroup O128 hybridised with the VT probes. One strain of serotype O128ab:H2 hybridised with VT1 and VT2 probes and two strains, serotypes O128ab:H2 and O128ab: H31, hybridised with the VT1 probe alone.

both probes (tables I and II). Fifteen of these strains belonged to serogroups $\mathrm{O} 26$ or $\mathrm{O} 128$, confirming the results of previous studies. ${ }^{3,18}$ The remaining VTEC strain was of serotype O111ac: H8.

\section{Discussion}

EAF-positive EPEC strains belonging to serotypes associated with outbreaks of infantile enteritis in the UK are still being isolated from sporadic cases of diarrhoea. ${ }^{22}$ The present study confirms this observation and also demonstrates that these EAF-positive strains form a low proportion, $c .8 \%$, of strains isolated from cases of diarrhoea and belonging to 13 EPEC $O$ serogroups. The results also demonstrate that EAF-positive strains are rare in healthy children in the UK; none was detected in 115 faecal specimens examined in this study. In some common $\mathrm{O}$ groups such as $\mathrm{O} 18, \mathrm{O} 26$ and O128, all 116 strains isolated in the UK gave negative results in tests with the EAF probe and within certain serogroups the majority of EAFnegative strains belonged to only one $\mathrm{H}$ type. The EAF-negative strains were isolated from patients with diarrhoea but it is not known if these strains can cause disease. Such strains may be useful in further studies to determine whether other virulence mechanisms are important in diarrhoeal disease. In the present study, Vero cytotoxin production was detected in a small proportion (4\%) of strains. Several strains of serotype $\mathrm{O} 26: \mathrm{H} 11$ have been shown to produce VT and Levine et al. ${ }^{30}$ suggested that such $\mathrm{O} 26$ strains belonged to the group of $E$. coli termed enterohaemorrhagic $E$. coli, or EHEC, since they have been associated with bloody diarrhoea. Other serogroups such as $\mathrm{O} 111$ and $\mathrm{O} 128$ are heterogeneous in their virulence properties with some strains being EAF-positive while other members produce VT or enterotoxins ST and LT. For example, in previous studies, strains of serogroup O128 were shown to produce ST, LT, ST and LT, or VT and some strains adhered to HEp-2 cells. $^{4,22,31}$ The $\mathrm{O} 128$ strains adhering to HEp-2 cells in a localised pattern could be divided into two groups-strains that hybridised with the EAF probe and others that did not. ${ }^{15,22}$ In the present study only the EAF-positive strains were tested for adhesion to HEp- 2 cells and it is likely that some of the EAF-negative strains could adhere to HEp-2 cells in a localised manner.

A possible disadvantage in using probes is that they may detect strains that have the required gene sequences but do not express the property associated with the genes. In this study two of $36 \mathrm{EAF}$-positive strains showed little (strain E36594) or no (strain E29452) adhesion to HEp-2 cells. Levine et al. ${ }^{16}$ reported that not all EAF-positive strains showed localised adhesion but details of the non-adherent 
EAF-positive strains were not given. $E$. coli strains that hybridised with the EAF probe but did not adhere have been constructed in this laboratory by transfer of EAF plasmids into wild-type strains of the non-EPEC serogroups O40, O71 and O99, and it was concluded that these wild-type strains lack additional chromosomal genetic information that is needed for the complete adhesion mechanism. ${ }^{32}$ Knutton et al. ${ }^{33,34}$ have suggested that EPEC adhesion involves a two-step process consisting of an initial binding to the cell surface followed by attachment with close cell-to-cell contact. The plasmid-mediated EAF is associated with the first stage of adhesion but does not seem to be required for the intimate attachment. In the second stage there is production of a characteristic "attaching and effacing" lesion in which there is destruction of the microvilli and close attachment of the bacteria to cup-like projections of the enterocyte membrane. These processes are thought to require chromosomally-encoded factors. Strains E36594 and E29452 may have mutations in either plasmid or chromosomal genes leading to the observed low level or absence of HEp-2 adhesion. EAF-positive

\section{REFERENCES}

1. Taylor J. Host specificity and enteropathogenicity of Escherichia coli. J Appl Bacteriol 1961 ; 24 : 316-325.

2. Gross R J, Scotland S M, Rowe B. Enterotoxin testing of Escherichia coli causing epidemic infantile enteritis in the UK. Lancet 1976; 1: 629-631.

3. Scotland S M, Day N P, Rowe B. Production of a cytotoxin affecting Vero cells by strains of Escherichia coli belonging to traditional enteropathogenic serogroups. FEMS Microbiol Lett 1987; 7: 15-17.

4. Cravioto A, Gross R J, Scotland S M, Rowe B. An adhesive factor found in strains of Escherichia coli belonging to the traditional infantile enteropathogenic serotypes. Curr Microbiol 1979; 3: 95-99.

5. Scaletsky I C A, Silva M L M, Trabulsi L R. Distinctive patterns of adherence of enteropathogenic Escherichia coli to HeLa cells. Infect Immun 1984; 45 : 534-536.

6. Nataro J P, Kaper J B, Robins-Browne R, Prado V, Vial P, Levine M M. Patterns of adherence of diarrheagenic Escherichia coli to HEp-2 cells. Pediatr Infect Dis J 1987; 6: $829-831$.

7. Vial $\mathbf{P} \mathrm{A}, \mathrm{Robins}-\mathrm{Browne} \mathrm{R}$, Lior $\mathrm{H}$ et al. Characterization of enteroadherent-aggregative Escherichia coli, a putative agent of diarrheal disease. $J$ Infect Dis 1988; 158: 70-79.

8. Baldini M M, Kaper J B, Levine M M, Candy D C A, Moon $\mathrm{H}$ W. Plasmid-mediated adhesion in enteropathogenic Escherichia coli. J Pediatr Gastroenterol Nutr 1983; 2: 534-538.

9. Nataro J P, Baldini M M, Kaper J B, Black R E, Bravo N, Levine $\mathbf{M}$ M. Detection of an adherence factor of enteropathogenic Escherichia coli with a DNA probe. $J$ Infect Dis 1985; 152: 560-565.

10. Levine M M, Nataro J P, Karch $\mathrm{H}$ et al. The diarrheal strains attach to Intestine 407 cells $^{22}$ and the mutations in E36594 and E29452 also affected attachment to this cell line. The FAS test has been developed to identify strains with this "attaching and effacing" ability. ${ }^{26}$ Fluorescein-labelled phallotoxin binds specifically to filamentous actin enabling visualisation of microfilaments produced when EPEC and other strains adhere to tissue culture cells. As strain E36594 gave some attachment it was possible to show this strain was FAS test-positive and so was presumably not defective in genes relating to this property. Further studies are necessary to investigate the mutations in strain E36594 and also in strain E29452 that showed no adhesion.

The present study has shown that EAF and VT genes in strains belonging to EPEC $O$ serogroups are found in a limited range of $\mathrm{O}: \mathrm{H}$ combinations and some non-motile strains. Further studies are required to investigate the properties of the large number of EAF-negative EPEC strains of other $\mathrm{O}: \mathrm{H}$ combinations and any role they may play in diarrhoeal disease.

response of humans to some classic serotypes of enteropathogenic Escherichia coli is dependent on plasmid encoding an enteroadhesiveness factor. $J$ Infect Dis 1985 ; 152: 550-559.

11. Baldini M M, Nataro J P, Kaper J B. Localization of a determinant for HEp-2 adherence by enteropathogenic Escherichia coli. Infect Immun 1986; 52: 334-336.

12. Nataro J P, Scaletsky I C A, Kaper J B, Levine M M, Trabulsi L R. Plasmid-mediated factors conferring diffuse and localized adherence of enteropathogenic Escherichia coli. Infect Immun 1985; 48: 378-383.

13. Echeverria P, Taylor D N, Donohue-Rolfe A et al. HeLa cell adherence and cytotoxin production by enteropathogenic Escherichia coli isolated from infants with diarrhea in Thailand. J Clin Microbiol 1987; 25: 15191523.

14. Chatkaeomorakot A, Echeverria P, Taylor D N et al. HeLa cell-adherent Escherichia coli in children with diarrhea in Thailand. J. Infect Dis 1987; 156: 669-672.

15. Chart H, Scotland S M, Willshaw G A, Rowe B. HEp-2 adhesion and the expression of a $94 \mathrm{kDa}$ outermembrane protein by strains of Escherichia coli belonging to enteropathogenic serogroups. J Gen Microbiol $1988 ; 134: 1315-1321$.

16. Levine M M, Prado V, Robins-Browne R et al. Use of DNA probes and HEp-2 cell adherence assay to detect diarrheagenic Escherichia coli. J Infect Dis 1988; 158: 224-228.

17. Konowalchuk J, Speirs J I, Stavric S. Vero response to a cytotoxin of Escherichia coli. Infect Immun 1977; 18: 775-779.

18. Smith H R, Scotland S M, Chart H, Rowe B. Vero cytotoxin production and presence of VT genes in strains of Escherichia coli and Shigella. FEMS Microbiol Lett 1987; 42 : 173-177. 
19. Scotland S M, Smith H R, Rowe B. Two distinct toxins active on Vero cells from Escherichia coli O157. Lancet $1985 ; 2: 885-886$.

20. Willshaw G A, Smith H R, Scotland S M, Field A M, Rowe B. Heterogeneity of Escherichia coil phages encoding Vero cytotoxins: comparison of cloned sequences determining VT1 and VT2 and development of specific gene probes. J Gen Microbiol 1987; 133 : 1309-1317.

21. Robins-Browne R M. Traditional enteropathogenic Escherichia coli of infantile diarrhea. Rev Infect Dis 1987; 9: 28-53.

22. Scotland S M, Willshaw G A, Smith H R, Gross R J, Rowe B. Adhesion to cells in culture and plasmid profiles of enteropathogenic Escherichia coli isolated from outbreaks and sporadic cases of infant diarrhoea. $J$ Infect $1989 ; 19: 237-249$.

23. Cowan S T. Cowan and Steel's manual for the identification of medical bacteria, 2nd edn. Cambridge, Cambridge University Press. 1974.

24. Gross R J, Rowe B. Serotyping of Escherichia coli. In: Sussman M (ed) The virulence of Escherichia coli. Reviews and Methods. London, Academic Press. 1985: 345-363.

25. Scotland S M, Richmond J E, Rowe B. Adhesion of enteropathogenic strains of Escherichia coli (EPEC) to HEp-2 cells is not dependent on the presence of fimbriae. FEMS Microbiol Lett 1983; 20 : 191-195.

26. Knutton S, Baldwin T, Williams P H, McNeish A S. Actin accumulation at sites of bacterial adhesion to tissue culture cells: basis of a new diagnostic test for enteropathogenic and enterohemorrhagic Escherichia coli. Infect Immun 1989; 57: 1290-1298.
27. Maniatis T, Fritsch E F, Sambrook J. Molecular Cloning: A Laboratory Manual. Cold Spring Harbor, New York, Cold Spring Harbor Laboratory, 1982.

28. Willshaw G A, Smith H R, Scotland S M, Rowe B. Cloning of genes determining the production of Vero cytotoxin by Escherichia coli. J Gen Microbiol 1985; 131: 30473053

29. Feinberg A P, Vogelstein B. A technique for radiolabeling DNA restriction endonuclease fragments to high specific activity. Anal Biochem 1983; 132: 6-13.

30. Levine M M, Xu J G, Kaper J B et al. A DNA probe to identify enterohemorrhagic Escherichia coli of O1 57:H7 and other serotypes that cause hemorrhagic colitis and hemolytic uremic syndrome. J Infect Dis 1987; 156: 175-182.

31. Thomas L V, Scotland S M, Rowe B. Enterotoxigenic strains of Escherichia coli serogroup O128 are not restricted to subgroup ac but also belong to subgroups $a b$ and abc. Infect Immun 1987; 55: 1336-1337.

32. McConnell M M, Chart H, Scotland S M, Smith H R, Willshaw G A, Rowe B. Properties of adherence factor plasmids of enteropathogenic Escherichia coli and the effect of host strain on expression of adherence to HEp2 cells. J Gen Microbiol 1989; 135: 1123-1134.

33. Knutton S, Baldini M M, Kaper J B, McNeish A S. Role of plasmid-encoded adherence factors in adhesion of enteropathogenic Escherichia coli to HEp-2 cells. Infect Immun 1987; 55: 78-85.

34. Knutton S, Lloyd D R, McNeish A S. Adhesion of enteropathogenic Escherichia coli to human intestinal enterocytes and cultured human intestinal mucosa. Infect Immun 1987; 55: 69-77. 